\title{
Aplikasi Problem Based Learning berbantuan MOODLE untuk Menumbuhkan Self Regulated Learning Siswa dan Meningkatkan Hasil Belajar Siswa pada Materi Ekologi Kelas X IPA 2 (SMA Negeri 3 Jember) Problem Based Learning Application through MOODLE for the Students' Growing Self Regulated Learning and Improving the XIPA 2 Grade Students' Learning Outcomes in the Ecology at SMAN 3 Jember
}

Lailiyah Maghfiroh, Wachju Subchan, Mochammad Iqbal.

Program Studi Pendidikan Biologi, Pendidikan MIPA, FKIP, Universitas Jember

Jln. Kalimantan 37, Jember 68121

E-mail:wsubchan@gmail.com

\begin{abstract}
Abstrak
Salah satu model pembelajaran yang dapat menjadikan siswa mergulasi dirinya untuk belajar atau Self Regulated Learning (SRL) dalam proses pembelajaran adalah model pembelajaran Problem Based Learning berbantuan MOODLE. Penelitian ini bertujuan untuk menumbuhkan SRL siswa dan hasil belajar siswa dengan menerapkan model pembelajaran Problem Based Learning berbantuan MOODLE pada materi Ekologi siswa kelas X IPA 2 SMA Negeri 3 Jember tahun pelajaran 2014/2015. Jenis penelitian ini adalah Penelitian Tindakan Kelas (PTK) yang dilaksanakan sebanyak 2 siklus. Metode pengumpulan data menggunakan metode observasi, wawancara, dokumentasi, dan metode tes. Desain penelitian ini menggunakan model siklus Kemmis \& McTaggart. Hasil penelitian menunjukkan bahwa terdapat pertumbuhan SRL siswa pada pembelajaran Ekologi. SRL siswa meningkat sebanyak $43 \%$ mulai dari pra siklus hingga pasca siklus. Penelitian juga menunjukkan dapat meningkatkan hasil belajar siswa pada aspek kognitif secara klasikal, yaitu pada pra siklus memiliki persentase ketuntasan belajar siswa secara klasikal sebesar 8,82\%. Peningkatan hasil belajar siswa dari pra siklus ke siklus 2 sebesar 76,47\%. Hasil belajar aspek afektif secara klasikal pada siklus 1 sebanyak $78,82 \%$, dan meningkat pada siklus 2 menjadi $83,9 \%$. Kemudian, pada hasil belajar aspek psikomotorik menunjukkan secara klasikal siswa yang semakin meningkat dengan persentase $82,17 \%$ pada siklus 1 dan meningkat menjadi $88,11 \%$ pada siklus 2 sehingga meningkat $5,94 \%$.
\end{abstract}

Kata Kunci: Model pembelajaran Problem Based Learning, MOODLE, Self Regulated Learning, hasil belajar.

One of learning model that can make the students do the regulation by themselves to learn or Self-Regulated Learning (SRL) in the teaching learning process is called as a Problem Based Learning model through MOODLE. This study aims to foster SRL for the students and the students" learning outcomes by implementing learning model "Problem Based Learning" through MOODLE on Ecology in the X IPA 2 grade students at SMAN 3 Jember in the 2014/2015 academic year. The research design is a classroom action research (AR) which has been done in two cycles. The data collection methods used in this research are observation, interviews, documentation, and test methods. This cycle model is adapted from Kemmis \& McTaggart. The results of the research showed that the students'SRL growth is increased as much as 43\% from pre cycle to post cycle. The research has also shown that the students' learning outcomes on cognitive aspects were increased in the classical style. The percentage of the students in the pre-cycle is $8.82 \%$. Therefore, the students' learning result is improved from the first cycle to the second cycle as much as $76.47 \%$. The results of the research in affective aspects of classical learning in cycle 1 is $78.82 \%$, and it can be improved becomes $83.9 \%$ in cycle 2. Then, the percentage of the students' learning outcomes in the psychomotor aspects of classical learning is $82.17 \%$ in the first cycle and increased to $88.11 \%$ in the second cycle. Thus, the result of each cycle is increased as much as $5.94 \%$.

Keywords: Problem Based Learning model, MOODLE, Self Regulated Learning, students learning achievement

\section{Pendahuluan}

Memasuki abad ke-21, pendidikan di Indonesia dihadapkan dengan sejumlah tantangan dan peluang yang tentunya berbeda dengan jaman-jaman sebelumnya [1]. Tantangan-tantangan abad ke-21 ini diantaranya adalah menuntut sumber daya manusia yang berkualitas.
Sumberdaya manusia yang berkualitas dapat diperoleh dari pendidikan yang mempunyai visi untuk ikut serta secara aktif dalam membangun dunia yang baru, dunia yang didominasi oleh ilmu pengetahuan dan tekhnologi namun tetap berorientasi kepada nilai-nilai luhur [2]. Oleh karena itulah berbagai upaya dilakukan untuk memperbaiki mutu pendidikan demi tercapainya sumber daya manusia berkualitas. Upaya meningkatkan mutu pendidikan 
dipengaruhi oleh guru yang kreatif dan inovatof [3]. Kriteria keberhasilan mengajar tidak diukur sejauh mana siswa telah menguasai materi pelajaran saja, tetapi juga diukur sejauh mana siswa telah melakukan proses belajar [4]. Dengan demikian, guru tidak lagi berperan hanya sebagai sumber belajar, tetapi juga membimbing dan memfasilitasi agar siswa dapat meregulasi dirinya untuk mau dan mampu belajar (Self Regulated Learning) sehingga menciptakan hasil belajar yang diinginkan.

Hasil observasi awal melalui wawancara dengan guru Biologi kelas X IPA SMA Negeri 3 Jember bahwa hasil belajar biologi yang rendah. Menurut [5], siswa yang telah meregulasi diri dalam belajar dapat membawa siswa menjadi master (ahli/menguasai) dalam belajarnya sehingga terwujudnya hasil belajar yang diinginkan. Berdasarkan hasil belajar yang rendah membuktikan bahwa SRL siswa masih kurang. Hal tersebut terbukti dari hasil observasi bahwa SRL siswa kelas X IPA 2 masih dalam kategori rendah. Oleh karena itu, dibutuhkan suatu tindakan perbaikan untuk dapat menumbuhkan SRL siswa sehingga meningkatkan hasil belajar siswa kelas X IPA 2.

Metode pembelajaran yang mungkin dapat diterapkan salah satunya adalah Problem Based Learning. Problem Based Learning ini memiliki kelebihan yaitu menjadi lebih ingat dan meningkatkan pemahaman atas materi ajar, meningkatkan fokus pada pengetahuan yang relevan, mendorong untuk berfikir, membangun kerja tim, kepemimpinan, dan keterampilan sosial, membangun kecakapan belajar, memotivasi pebelajar, realistik dengan kehidupan siswa [6]. Selain itu Problem Based Learning memiliki kekurangan diantaranya adalah untuk siswa yang malas tujuan Problem Based Learning tidak dapat tercapai, membutuhkan banyak waktu dan dana, metode yang tidak selalu tepat digunakan pada semua mata pelajaran, serta sulitnya mencari problem yang relevan [7]. Permasalahan atau kekurangan Problem Based Learning tersebut maka perlu diadakannya strategi yang dapat melengkapi metode Problem Based Learning untuk mempermudah pemahaman siswa dalam memecahkan masalah pada materi yang diberikan karena metode ini membutuhkan siswa untuk berpikir kritis, maka perlu dilengkapi pembelajaran learning. Menurut [8] pembelajaran melalui e-learning ini bersifat fleksibel yang memungkinkan pengguna e-learning dapat mengakses tanpa dibatasi oleh waktu dan tempat. Pembelajaran melaui e-learning dapat menggunakan berbagai macam program aplikasi sebagai media pembelajaran, salah satunya adalah MOODLE. MOODLE adalah sebuah nama untuk program aplikasi yang dapat merubah sebuah media pembelajaran ke dalam bentuk web. MOODLE memungkinkan siswa untuk masuk ke dalam ruang kelas digital untuk mengakses materi-materi pembelajaran secara online. Melalui penggunaan MOODLE guru dapat membuat materi pembelajaran, kuis, jurnal elektronik dan lain-lain secara online.

Berdasarkan pemikiran di atas, pengaplikasian Problem Based Learning berbantuan MOODLE diharapkan dapat menuntun siswa untuk mencari tahu, mengapa suatu peristiwa terjadi, kemudian siswa melakukan kegiatan, mengumpulkan dan menganalisis data melalui fenomena kehidupan dilingkungan, sampai akhirnya siswa menemukan jawaban permasalahan tersebut tanpa dibatasi oleh waktu dan ruang. Jadi, pembelajaran melalui tatap muka dan diluar tatap muka tersebut membantu siswa untuk meregulasi dirinya untuk belajar dan menjadikan pembelajaran lebih bermakna.

Tujuan penelitian ini adalah untuk menumbuhkan SRL siswa dan meningkatkan hasil belajar siswa dengan pengaplikasian Problem Based Learning berbantuan MOODLE pada materi Ekologi Kelas X IPA 2 SMA Negeri 3 Jember.

\section{Metode Penelitian}

Penelitian ini dilaksanakan di SMA Negeri 3 Jember pada semester genap tahun pelajaran 2014/2015 pada bulan Mei 2015. Subjek penelitian dalam penelitian ini adalah siswa kelas X IPA 2. Jenis Penelitian yang digunakan dalam penelitian ini adalah penelitian tindakan kelas (PTK). PTK yang dilaksanakan menggunakan model dari Kemmis \& McTaggart. Model ini merupakan pengembangan konsep dasar dari K. Lewin, hanya saja komponen tindakan (acting) dan pengamatan (observing) sebagai satu kesatuan. Model ini menjelaskan bahwa setiap perangkat berisi empat komponen sebagai siklus atau putaran kegiatan yang terdiri dari: perencanaan, tindakan, pengamatan, dan refleksi [9]. Metode yang digunakan untuk mengumpulkan data dalam penelitian ini adalah: metode observasi; metode wawancara; metode dokumentasi; metode tes. Metode analisis yang digunakan dalam penelitian ini adalah metode deskriptif kualitatif/dan kuantitatif. Analisis data dilaksanakan pada hasil observasi SRL siswa dan hasil belajar siswa (kognitif, afektif, psikomotor). Adapun data yang dianalisis adalah:

a) Tingkat pertumbuhan SRL siswa

Untuk mengetahui gambaran tingkat SRL baik secara

umum maupun spesifik, maka ditempuh langkah-langkah

sebagai berikut:

1) Statistika deskriptif dengan bantuan SPSS versi 16.0 for windows

2) Mencari skor tertinggi: jumlah item (n) $x$ skor tertinggi $\left(\mathrm{x}_{\mathrm{t}}\right)$

Mencari skor terendah: jumlah item (n) $\mathrm{x}$ skor tertinggi $\left(\mathrm{x}_{\mathrm{r}}\right.$

4) Mencari Rerata teoritis : jumlah item (n) $x 2,5$

5) Mencari standar deviasi:

Skor tertinggi $(\mathrm{xt})$ - skor terendah (xr)

6

6) Mencari kategori

Tujuan kategori ini adalah menentukan individu kedalam kelompok-kelompok terpisah secara berjenjang menuntut suatu kontium berdasarkan atribut yang diukur. Untuk penelitian ini akan digunakan jenis kategori jenjang dengan tiga jenjang penggolongan, yaitu:

Tabel 1. Penggolongan Kriteria Analisis berdasarkan Rerata Teoritis

\begin{tabular}{cc}
\hline Interval Skor & Kriteria \\
\hline$\mu+1 \sigma \leq X$ & Tinggi \\
\hline$\mu-1 \sigma \leq X<\mu+1 \sigma$ & Sedang \\
\hline
\end{tabular}




$\mathrm{X}<\mu-1 \sigma \quad$ Rendah

Keterangan:

$\mu:$ Rerata teoritis

$\sigma:$ Standar devisiasi [10]

b) Menentukan Prosentase SRL

Setelah melakukan kriteria dan mengetahui jumlah individu yang ada suatu kelompok, langkah selanjutnya yaitu menentukan prosentasenya yaitu dengan cara sebagai berikut :

$$
P=\frac{f}{F} \times 100
$$

Keterangan :

$\mathrm{P}=$ persentase

$\mathrm{F}=$ frekuensi

$\mathrm{N}=$ Jumlah subjek

c) Peningkatan hasil belajar yang diukur dalam penelitian ini adalah nilai ulangan harian sebagai penilaian kognitif, hasil observasi sebagai penilaian afektif dan psikomotor. Nilai ulangan harian siklus I dibandingkan dengan nilai pra siklus, sedangkan nilai siklus II dibandingkan dengan nilai siklus I, nilai ini digunakan untuk mengetahui kenaikan hasil belajar siswa persiklus ditinjau dari ranah kognitif, sehingga untuk mengetahui ketuntasan hasil belajar siswa berdasarkan aspek kognitif secara klasikal dapat dihitung menggunakan rumus :

Keterangan :

$$
P=\frac{m}{M} \times 100
$$

$\mathrm{P}=$ persentase ketuntasan hasil belajar secara klasikal $\mathrm{m}=$ Jumlah siswa tuntas

$\mathrm{M}=$ Jumlah siswa secara keseluruhan

Kriteria ketuntasan hasil belajar siswa dinyatakan sebagai berikut:

- daya serap perorangan, seorang siswa dikatakan tuntas apabila mencapai hasil $\geq 75$ dari nilai maksimal 100

- daya serap klasikal, suatu kelas dikatakan tuntas apabila telah mencapai minimal $85 \%$ siswa telah mendapat nilai $\geq 75$ dari nilai maksimal 100 (disesuaikan dengan KKM SMA Negeri 3 Jember)

Adapun untuk mengetahui ketuntasan hasil belajar siswa berdasarkan aspek afektif dan psikomotor secara klasikal dapat dihitung menggunakan rumus [11]:

$$
\begin{gathered}
\text { Hasil penilaian } \\
\text { afektif }
\end{gathered}=\frac{\sum \text { skor yang diperoleh }}{\begin{array}{c}
\sum \text { skor indikator } \\
\text { afektif/psikomotorik }
\end{array}} \times 100 \%
$$

Metode yang digunakan untuk mengumpulkan data dalam penelitian ini adalah (1) metode observasi; (2) metode wawancara; (3) metode dokumentasi; (4) metode tes.

\section{Hasil dan Pembahasan}

\section{a. Self Regulated Learning (SRL)}

Salah satu skala yang digunakan dalam penelitian in adalah skala SRL. Skala tersebut disusun berdasarkan indikator-indikator yang mempresentasikan variabel SRL.
Oleh karena itu, gambaran SRL siswa dapat ditinjau baik secara umum maupun spesifik (ditinjau dari tiap strategi). Tabel 4. Total Peningkatan SRL Pra Siklus hingga Pasca siklus

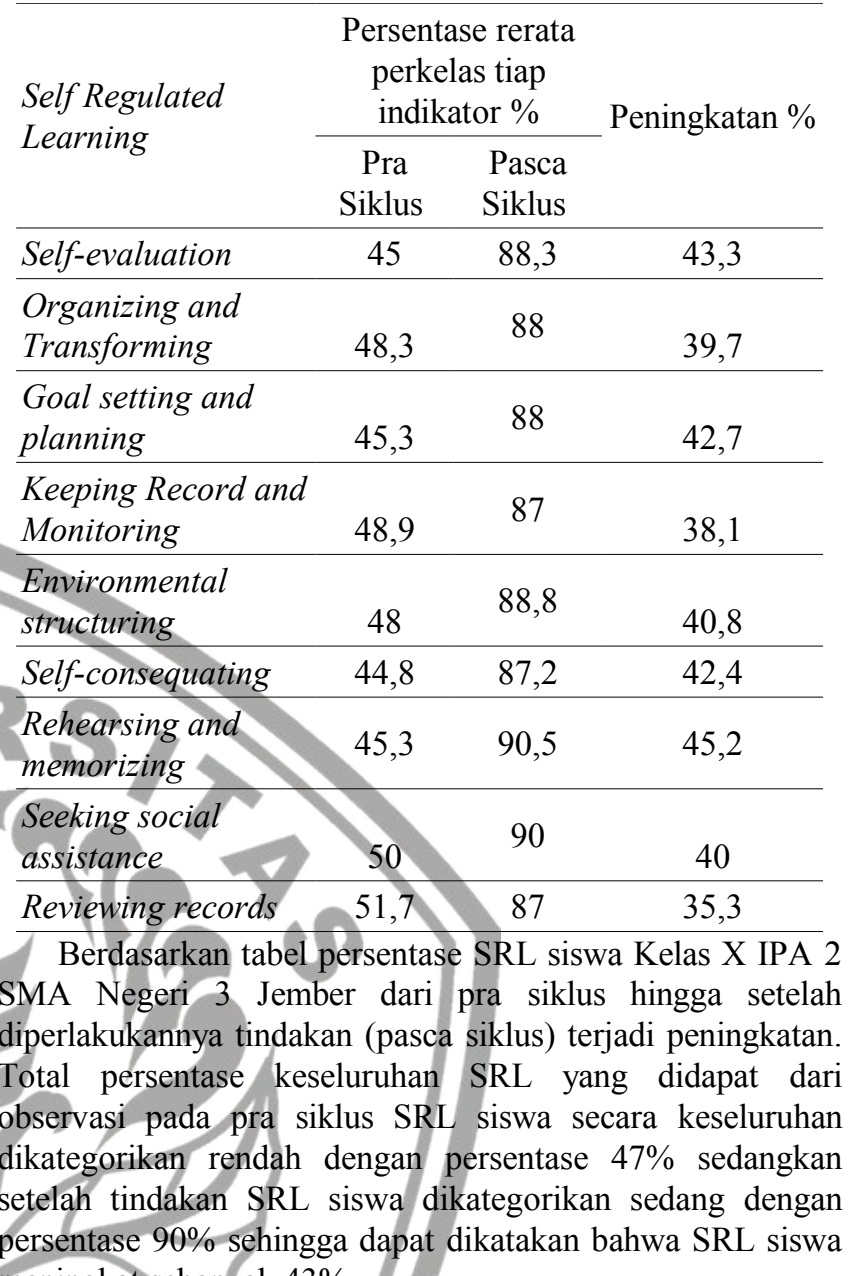

meningkat sebanyak $43 \%$.

b. Hasil Belajar Siswa

Hasil belajar siswa yang diukur meliputi hasil belajar kognitif berupa nilai tes hasil belajar yang dilaksanakan tiap akhir siklus dan hasil belajar afektif siswa, meliputi sikap disiplin, tanggungjawab, sopan, menghargai pendapat, dan kemampuan bertanya. Hasil belajar psikomotorik siswa yang di nilai meliputi kesiapan mengikuti diskusi kelas dan menyimak penjelasan diskusi kelas. Adapun persentase hasil belajar siswa adalah sebagai berikut.

1) Ketuntasan Hasil Belajar Kognitif Siswa

Tabel 5. Ketuntasan Hasil Belajar Kognitif

\begin{tabular}{ccccc}
\hline $\begin{array}{c}\text { Tahap } \\
\text { pembelajaran }\end{array}$ & Nilai & $\begin{array}{c}\text { Jumlah } \\
\text { siswa }\end{array}$ & $\begin{array}{c}\text { Persentase } \\
(\%)\end{array}$ & $\begin{array}{c}\text { Rerata } \\
\text { kelas } \pm \\
\text { SD }\end{array}$ \\
\hline Pra siklus & $\geq 75$ & 13 & 32,50 & $63,85 \pm$ \\
\cline { 2 - 4 } & $<75$ & 27 & 67,50 & 13,82 \\
\hline Siklus 1 & $\geq 75$ & 25 & 62,50 & $75,00 \pm$ \\
& $<75$ & 15 & 37,50 & 7,27 \\
\hline Siklus 2 & $\geq 75$ & 35 & 87,50 & $80,42 \pm$ \\
& $<75$ & 5 & 12,50 & 4,90 \\
\hline Peningkatan dari pra siklus hingga & 30 & 11,15 \\
\hline
\end{tabular}




\begin{tabular}{l}
\hline siklus 1 (\%) \\
$\begin{array}{l}\text { Peningkatan dari siklus 1 hingga } \\
\text { siklus 2 (\%) }\end{array}$ \\
\hline
\end{tabular}

Berdasarkan tabel ketuntasan hasil belajar siswa tersebut dapat diketahui peningkatan keaktifan belajar siswa dari prasiklus, siklus I, dan siklus II yang dapat dilihat pada Gambar 1 berikut.

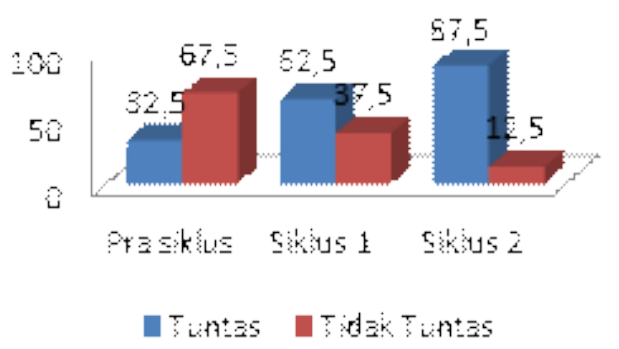

Gambar 1. Histogram Analisis Peningkatan Hasil Belajar Kognitif

2) Hasil Belajar Afektif dan Psikomotorik

Penerapan model pembelajaran Problem Based Learning berbantuan MOODLE dapat meningkatkan hasil belajar siswa pada aspek kognitif secara klasikal, yaitu pada pra siklus memiliki persentase ketuntasan belajar siswa secara klasikal sebesar 8,82\%, siklus 1 memiliki persentase $52,94 \%$ dan siklus 2 memiliki persentase sebesar 85,29\%. Peningkatan hasil belajar siswa dari pra siklus ke siklus 2 sebesar $76,47 \%$. Hasil belajar aspek afektif secara klasikal pada siklus 1 sebanyak $78,82 \%$, dan meningkat pada siklus 2 menjadi $83,9 \%$. Kemudian, pada hasil belajar aspek psikomotorik menunjukkan secara klasikal siswa yang semakin meningkat dengan persentase $82,17 \%$ pada siklus 1 dan meningkat menjadi $88,11 \%$ pada siklus 2. Adapun peningkatan hasil belajar siswa aspek afektif dan aspek psikomotor tergambar dalam Gambar 2 dan Gambar 3 sebagai berikut.

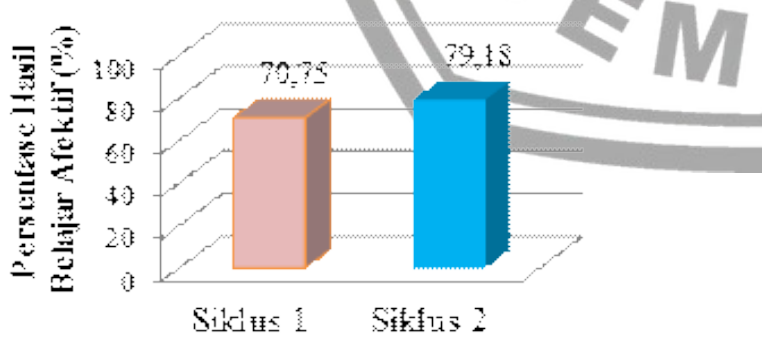

Gambar 2. Peningkatan Hasil Belajar Aspek Afektif

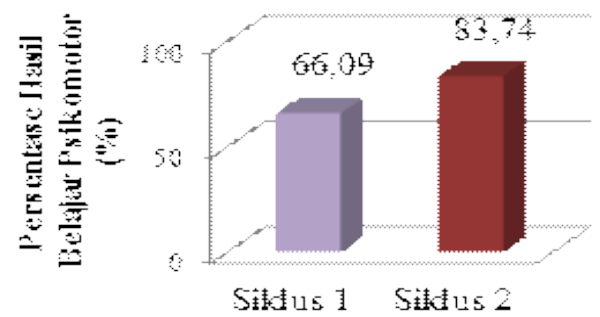

Gambar 3. Peningkatan Hasil Belajar Aspek Psikomotorik
Penelitian yang dilakukan ini merupakan penelitian tindakan kelas (PTK) yang dilaksanakan di kelas X IPA 2 SMA Negeri 3 Jember. Penelitian ini bertujuan untuk meningkatkan SRL siswa dan hasil belajar pada pelajaran Biologi dengan model pembelajaran Problem Based Learning berbantuan MOODLE. Penelitian ini dilakukan dalam 2 siklus. Siklus 1 dan siklus 2 masing-masing terdiri atas 3 pertemuan, 2 pertemuan untuk proses pembelajaran dan 1 pertemuan untuk ujian. Berdasarkan data hasil penelitian yang telah dilakukan terlihat bahwa SRL dan hasil belajar siswa meningkat mulai dari pra siklus, siklus 1 dan siklus 2 .

Menurut [6], pembelajaran Problem Based Learning yaitu suatu model pengajaran yang menggunakan masalah dunia nyata sebagai konteks bagi siswa untuk belajar cara berpikir kritis dan keterampilan pemecahan masalah untuk memperoleh pengetahun dan konsep essensial dari materi pelajaran. Adapun MOODLE menurut [12] merupakan aplikasi atau program LMS (Learning Managment System) berupa e-learning, sehingga siswa dapat mengakses materimateri pembelajaran berupa video, gambar, dan suara serta dapat memberikan respon yang aktif. Respon aktif tersebut menentukan kecepatan dan sekuensi penyajian. Menurut [13] model pembelajaran dengan menggunakan e-learning berbasis web, minat belajar siswa semakin meningkat, proses belajarpun dirasakan menarik dan tidak membosankan hal tersebut dikarenakan siswa secara aktif terlibat langsung dalam pembelajaran.

Jadi, penerapan Problem Based Learning apabila dipadukan dengan MOODLE akan mampu mengajak siswa untuk memantau, mengatur dan mengontrol kognisi, motivasi, dan perilaku yang diorientasikan atau diarahkan pada tujuan belajar. Sehingga siswa lebih aktif dalam pembelajaran serta lebih mudah dalam memahami materi pelajaran dikarenakan adanya bimbingan yang dilakukan oleh guru di dalam atau di luar pembelajaran. Berdasarkan pembelajaran yang telah dilakukan peneliti, respon siswa pada pembelajaran yang dilakukan baik.

a) Peningkatan Self Regulated Learning (SRL)

1) Peningkatan SRL keseluruhan

SRL merupakan usaha aktif dan mandiri peserta didik dengan memantau, mengatur dan mengontrol kognisi, motivasi, dan perilaku, yang berorientasikan atau diarahkan pada tujuan belajar [14]. Penerapan model pembelajaran Problem Based Learning berbantuan MOODLE dapat meningkatkan SRL siswa kelas X IPA 2 SMA Negeri 3 Jember pada materi Ekologi, yaitu pada pra siklus SRL siswa secara keseluruhan dikategorikan rendah dengan persentase $47 \%$ sedangkan setelah tindakan SRL siswa dikategorikan sedang dengan persentase $90 \%$ sehingga dapat dikatakan bahwa SRL siswa meningkat sebanyak $43 \%$. Hal ini menggambarkan bahwa siswa cukup memiliki keterampilan tentang bagaimana belajar (how to learn) yang mencakup pemahaman tentang kemampuan berpikir, proses berpikir, dan motivasi untuk mencapai tujuan belajar [15].

2) Peningkatan SRL setiap indikator

Berdasarkan hasil analisis deskriptif indikator selfevaluation sebelum tindakan dalam kategori rendah yaitu dengan prosentase $45 \%$, setelah diberikan perlakuan atau tindakan maka self-evaluation mencapai $88 \%$ sehingga 
kenaikan sebesar $43 \%$. Hal ini menunjukkan siswa cukup baik dalam melakukan evaluasi secara mandiri terhadap kualitas tugas dan proses belajar yang siswa jalani sehingga tujuan tercapai. Sehingga hal ini juga menunjukkan siswa dalam evaluasi diri dapat berinisiatif mengevaluasi kualitas atau kemajuan pekerjaan yang dilakukan [5].

Organizing and transforming siswa sebelum tindakan dalam kategori rendah yaitu dengan prosentase 48,3\% Setelah diberikan perlakuan atau tindakan maka organizing and transforming siswa dikategorikan sedang $88 \%$ sehingga kenaikan sebesar $39,7 \%$. Maka hal ini berarti subjek cukup baik dalam mengorganisasi materi pelajarandan dan dapat mentransformasikan atau mengubahnya kedalam bentuk yang sederhana sehingga memudahkan dalam belajar [16]. Sebelum tindakan dalam goal setting and planning siswa kategori rendah yaitu dengan prosentase $45,3 \%$, setelah tindakan menjadi $87 \%$ sehingga kenaikan sebesar $38,1 \%$. Maka hal ini berarti subjek cukup baik dalam menetapkan tujuan yang ingin dicapai dalam belajar dan membuat perencanaan baik dalam hal prioritas tugas, alokasi waktu dan aktivitas yang mendukung belajar [17]

Keeping record and monitoring sebelum tindakan dalam kategori rendah yaitu dengan prosentase $48,9 \%$, setelah di berikan tindakan presentase $87 \%$ sehingga kenaikan sebesar 38,1\%. Hal ini menunjukkan subjek cukup baik dalam melakukan perekaman proses dan hasil pelajaran serta dapat memantau kegiatan belajarnya secara mandiri agar tetap pada koridornya. Sehingga hal ini juga menunjukkan siswa dapat berupaya untuk merekam dan memantau peristiwa atau hasil [18].

Kenaikan Environment structuring setelah diberikan perlakuan sebesar $42,2 \%$ dengan kategori rendah menjadi kategori sedang. Maka hal ini berarti subjek cukup baik dalam mengatur lingkungan secara fisik agar mendukung kegiatan belajarnya [14].

Menurut [19] berdasarkan aspek strategi motivasi untuk mewujudkan SRL diantaranya adalah selfconsequating yaitu menentukan dan menyediakan konsekuensi ekstrensik untuk keterlibatan siswa pada kegaiatan belajar. Hal tersebut dibuktikan dengan hasil deskriptif indikator self-consequating sebelum tindakan dalam kategori rendah yaitu dengan prosentase $44,8 \%$ dan naik dengan kategori sedang menjadi $87 \%$ sehingga kenaikan sebesar $42,2 \%$.

Hasil analisis deskriptif indikator rehearsing and memorizing sebelum tindakan dalam kategori rendah yaitu dengan prosentase $45,3 \%$ setelah tindakan meningkat dengan kategori sedang dengan persentase $91 \%$ sehingga kenaikan sebesar 45,7\%. Maka hal ini berarti subjek cukup baik dalam upaya mengulang dan mengingat kembali materi pembelajaran yang telah dipelajari sebelumnya agar dapat mencapai tujuan belajarnya [16].

Seeking social assistance sebelum tindakan dalam kategori rendah yaitu dengan persentase $50 \%$ setelah diberikan perlakuan maka siswa dikategorikan dalam kategori sedang yaitu $90 \%$ sehingga kenaikan sebesar $40 \%$. Maka hal ini berarti subjek cukup baik dalam upaya mencari bantuan yang sesuai dengan lingkungan sosial (guru dan teman sebaya) guna membantu dirinya dalam mencapai tujuan belajar [20].
Reviewing record sebelum tindakan dalam kategori rendah yaitu dengan persentase $51,7 \%$ setelah tindakan maka reviewing records siswa dikategorikan dalam kategori sedang yaitu dengan persentase $87 \%$ sehingga kenaikan sebesar 35,3\%. Maka hal ini berarti subjek cukup baik dalam melakukan perekaman proses dan hasil pembelajaran dan memantau kegiatan belajarnya secara mandiri agar tetap pada koridor [17].

Indikator terakhir yaitu others yaitu faktor lain yang menunjukkan perilaku belajar yang diprakarsai oleh faktor lain [18]. Dalam hal ini diantaranya adalah regulasi metakognisi diri siswa atau metacognitive self-regulation. Menurut [19] aspek-aspek SRL diantaranya adalah metacognitive self-regulation, yaitu meliputi berbagai perencanaan, monitoring, dan regulasi strategi seperti menetapkan tujuan dari kegiatan membaca, memantau pemahaman sebagai salah satu bacaan, dan membuat perubahan atau penyesuaian dalam belajar sebagai salah satu kemajuan melalui sebuah tugas. Perencanaan strategi belajar tersebut dilakukan oleh siswa selama pemberian tindakan. Hal ini dibuktikan dengan hasil analisis deskriptif pada indikator others sebelum tindakan dalam kategori rendah yaitu dengan prosentase $48,3 \%$ Setelah diberikan perlakuan maka dikategorikan sedang yaitu dengan persentase $85 \%$ sehingga kenaikan sebesar $36,7 \%$.

b) Peningkatan Hasil Belajar Siswa Hasil belajar siswa dengan penerapan model pembelajaran Problem Based Learning berbantuan MOODLE, yaitu dari ketuntasan $32,50 \%$ menjadi $62,50 \%$ dengan peningkatan $30 \%$, akan tetapi untuk ketuntasan hasil belajar tersebut belum mencapai target yaitu ketuntasan klasikal yang telah ditetapkan di SMA Negeri 3 Jember yakni $\geq 85 \%$ dari seluruh siswa yang mendapat nilai $\geq 75$, sehingga perlu adanya tindakan perbaikan agar dapat menyelesaikan permasalahan di kelas X IPA 2 SMA Negeri 3 Jember. Faktor yang menyebabkan masih belum mencapai ketuntasan hasil belajar aspek kognitif tersebut salah satunya adalah siswa masih cukup kebingungan atau belum terbiasa dengan penggunaan aplikasi MOODLE. Hal tersebut sejalan dengan penelitian terdahulu [13] bahwa paenerapan pembelajaran berbasis e-learning, diperlukan guru ataupun siswa memperoleh pelatihan khusus atau kebiasaan dalam pembelajaran dengan menggunakan e-learning. Hasil belajar siswa pada siklus 2 meningkat sebanyak $25 \%$. Hal ini menunjukkan bahwa keberhasilan pembelajaran tidak hanya dari guru tetapi juga kemauan siswa untuk belajar, atau dengan kata lain SRL siswa tumbuh dalam diri siswa. Hal tersebut sejalan dengan pendapat [21] yang menyatakan bahwa siswa yang memiliki SRL menunjukkan seperangkat keyakinan motivasional dan emosi yang adaptif, seperti tingginya keyakinan diri secara akademik, memiliki tujuan belajar, mengembangkan emosi positif terhadap tugas (senang, antusias, dan puas) memiliki kemampuan untuk mengontrol dan memodifikasi, serta menyesuaikan diri dengan tuntutan tugas dan situasi belajar khusus sehingga tujuan pembelajaran siswa tercapai dengan baik.

Hasil belajar afektif siswa juga mengalami peningkatan yakni berdasarkan analisis hasil belajar aspek afektif secara klasikal juga menunjukkan adanya peningkatan hasil belajar 
selama siklus 1 dan siklus 2. Hasil belajar aspek afektif pada siklus 1 sebanyak $78,82 \%$, dan meningkat pada siklus 2 sebanyak $87,5 \%$. Peningkatan hasil belajar aspek afektif secara klasikal tidak begitu besar, namun disetiap pertemuan terdapat perubahan ke arah yang lebih baik.

Hasil belajar psikomotorik siswa juga meningkat, yakni berdasarkan analisis data hasil belajar aspek psikomotorik menunjukkan secara klasikal siswa yang semakin meningkat, hal ini ditunjukkan dengan persentase $66,09 \%$ pada siklus 1 dan meningkat menjadi $83,74 \%$ pada siklus 2 . Meningkatnya hasil belajar siswa aspek psikomotorik, semakin menunjukkan bahwa dalam proses belajar siswa juga membutuhkan proses untuk dapat melakukan sesuatu yang bisa menunjang pemahaman mereka terhadap materi yang sedang mereka pelajari.

Capaian rerata nilai afektif maupun psikomotorik pada siklus 1 khususnya pertemuan pertama sudah baik meskipun tidak sebaik pada siklus 2. Hal ini dikarenakan siswa belum terbiasa dengan kegiatan pembelajaran Problem Based Learning berbantuan MOODLE yakni pada pertemuan pertama siswa masih melakukan proses adaptasi terhadap model pembelajaran yang digunakan guru. Siswa juga masih membutuhkan waktu cukup lama dalam memahami permasalahan yang diberikan oleh guru. Hal ini merupakan proses belajar, siswa membentuk pola pikir untuk menerima atau menolak terhadap suatu yang baru. Menurut [22] belajar adalah perubahan tingkah laku yang didapat disebabkan adanya latihan dan pengalaman diri dalam interaksi dengan lingkungannya. Perubahan yang terjadi berbentuk kecakapan, keterampilan, maupun sikap. Jadi, tahapan perbaikan hasil belajar dalam ranah afektif ini dapat dikatakan bahwa siswa sudah mulai menerima terhapadap model pembelajaran Problem Based Learning berbantuan MOODLE yang diterapkan oleh guru peneliti.

Hasil wawancara dengan sebagian siswa menunjukkan bahwa siswa lebih bersemangat dan antusias dalam mengikuti proses pembelajaran di kelas. Adanya pengamatan maupun percobaan secara langsung membuat siswa lebih memahami materi pembelajaran dan kegiatan diskusi membuat siswa dapat berinteraksi serta bekerjasama dengan kelompoknya. Wawancara dengan guru juga menyatakan bahwa model pembelajaran yang digunakan dalam penelitian ini dapat meningkatkan aktivitas siswa, sehingga siswa menjadi lebih aktif dibandingkan ketika mengikuti proses pembelajaran sebelum-sebelumnya.

\section{Kesimpulan dan Saran}

Kesimpulan dari penelitian ini adalah penerapan model pembelajaran Problem Based Learning berbantuan MOODLE dapat meningkatkan SRL siswa kelas X IPA 2 SMA Negeri 3 Jember pada materi Ekologi, yaitu pada pra siklus SRL siswa secara keseluruhan dikategorikan rendah dengan persentase $47 \%$ sedangkan setelah tindakan SRL siswa dikategorikan sedang dengan persentase $90 \%$ sehingga dapat dikatakan bahwa SRL siswa meningkat sebanyak 43\%. Penerapan model pembelajaran Problem Based Learning berbantuan MOODLE dapat meningkatkan hasil belajar siswa pada aspek kognitif secara klasikal, yaitu pada pra siklus memiliki persentase ketuntasan belajar siswa secara klasikal sebesar $8,82 \%$, siklus 1 memiliki persentase 52,94\% dan siklus 2 memiliki persentase sebesar 85,29\%. Peningkatan hasil belajar siswa dari pra siklus ke siklus 2 sebesar 76,47\%. Hasil belajar aspek afektif secara klasikal pada siklus 1 sebanyak $78,82 \%$, dan meningkat pada siklus 2 menjadi 83,9\%. Kemudian, pada hasil belajar aspek psikomotorik menunjukkan secara klasikal siswa yang semakin meningkat dengan persentase $82,17 \%$ pada siklus 1 dan meningkat menjadi $88,11 \%$ pada siklus 2 .

Saran penelitian ini adalah sebagai berikut; Saat penerapan model pembelajaran Problem Based Learning berbantuan MOODLE hendaknya guru selalu membimbing dan mengawasi serta memberi semangat kepada siswa karena pelaksanaan pembelajaran ini membutuhkan keahlian khusus untuk menggunakan aplikasi e-learning. Hendaknya dalam penerapan penelitian ini lebih ditekankan dan diperjelas lagi permasalahan dalam bentuk fitur MOODLE yang lebih menarik sehingga siswa lebih antusias dalam mengikuti pembelajaran secara onlinenya

\section{Ucapan Terima Kasih}

Penulis mengucapkan terima kasih kepada Bapak dan Ibu guru SMA Negeri 3 Jember yang senantiasa memberikan bimbingan dan bentuannya selama penelitian dilaksanakan.

\section{Daftar Pustaka}

1] Sudrajat, Akhmad. 2013. Paradigma Pendidikan Indonesia Abad Ke-21. [on line]. https://akhmadsudrajat.com /2013/07/02/paradigmapendidikan-indonesia-abad-ke-21/. [27 Februari 2015].

2] Tilaar, H. A. R. 1998. Beberapa Agenda Reformasi Pendidikan Nasional dalam Perspektif Abad 21. Magelang: Tera Indonesia.

[3] Ihsan, F. 1996. Dasar-dasar Kependidikan. Jakarta: Rineka Cipta.

[4] Sanjaya, W. 2006. Strategi Pembelajaran. Jakarta: Kencana Prenada Media

[5] Zimmerman, Barry J. \& Schunk, Dale H. 1989. A Social Cognitive View of Self-Regulated Academic Learning. Journal of Educational Psychology, 3 (81): 329-339.

[6] Amir, T. 2013. Inovasi Pendidikan Melalui Problem Based Learning. Jakarta: Kencana.

[7] Trianto, 2010. Mendesain Model Pembelajaran Inovatif-Progesif. Jakarta: Kencana.

[8] Naidu, Som. 2006. E-Learning: A Guide of Principles, Procedures and Practices. Melbourne: The University of Melbourne.

[9] Depdiknas. 2010. Belajar Biologi. [on line]. http://www.depdiknas.go.id/Jurnal/42/ htm. [27 Februari 2015].

[10] Azwar, Saifuddin. 2011. Penyusunan Skala Psikologi Edisi 1 Cetakan $X V$. Yogyakarta: Pustaka Pelajar.

[11] Arikunto, S. 2011. Prosedur Penelitian Suatu Pendekatan Praktik. Jakarta: Rineka.

[12] Rahmasari \& Rismiati. 2013. E-learning Pembelajaran Jarak Jauh untuk SMA. Bandung: Yrama Widya.

[13] Wijaya, Muksin. 2012. Pengembangan Model Pembelajaran eLearning Berbasis Web dengan prinsip e-Pedagogy dalam Meningkatkan Hasil Belajar.

[14] Bell, P.D. dan Akroyd, D. 2006. Can Factors Related to Self Regulated Learning Predict Learning Achievement in Undergraduate Asynchronous Webbased Courses?. ISSN : 1550-6908.

[15] Deviyanti, R.A. 2011. "Pembelajaran Biologi dengan Pendekatan Kontekstual Model Pembelajaran Berbasis Masalah (Problem Based Learning) Untuk Meningkatkan Keterampilan Pemecahan Masalah dan Hasil Belajar (Siswa Biologi Kelas X Semester Gasal Tahun Pelajaran 2011/2012 SMAN 1 Prajekan, Bondowoso)". Tidak Diterbitkan. Skripsi. Jember : FKIP Universitas Jember. 
[16] Yulkselturk, E., \& Bulut, S. 2009. Gender differences in Self Regulated Online Learning Environment. Journal Educational Technology \& Society, 12 (3): 12-22

[17] Effeney, Gerard. et. al. 2013. Self-Regulated Learning: Key Strategi and Their Sources in a Sample of Adolescentt Males. Journal of Educational \& Developmental Psychology, 13: 58-74.

[18] Zimmerman, Barry J dan Martinez-Pons, Manuel. 1990. Student Difference in Self-Regulated Learning: Relating Grade, Sex, and Giftedness to Self-Efficacy and Strategy Use. Journal of Educational Psychology, 1 (82): 51-59.

[19] Wolters, C.A. 1998. Self Regulated Learning and Collage Student Regulation of Motivational. Jurnal of Education Psychology, 3 (80): 284-290.

[20] Winnie, P. H., \& Hadwin, A. F. (1998). Studying as Self-Regulated Learning and Academic Achievement. Jurnal of Psychology, 30: 173188.

[21] Montalvo, F.T \& Torres, M. C. G. 2004. Self-regulated Learning: Current and Future Direction. Journal of Research, 2 (1): 1-34. ISSN: 1696-2095

[22] Hamalik, O. 1999. Kurikulum dan Pembelajaran. Jakarta: Bumi Aksara

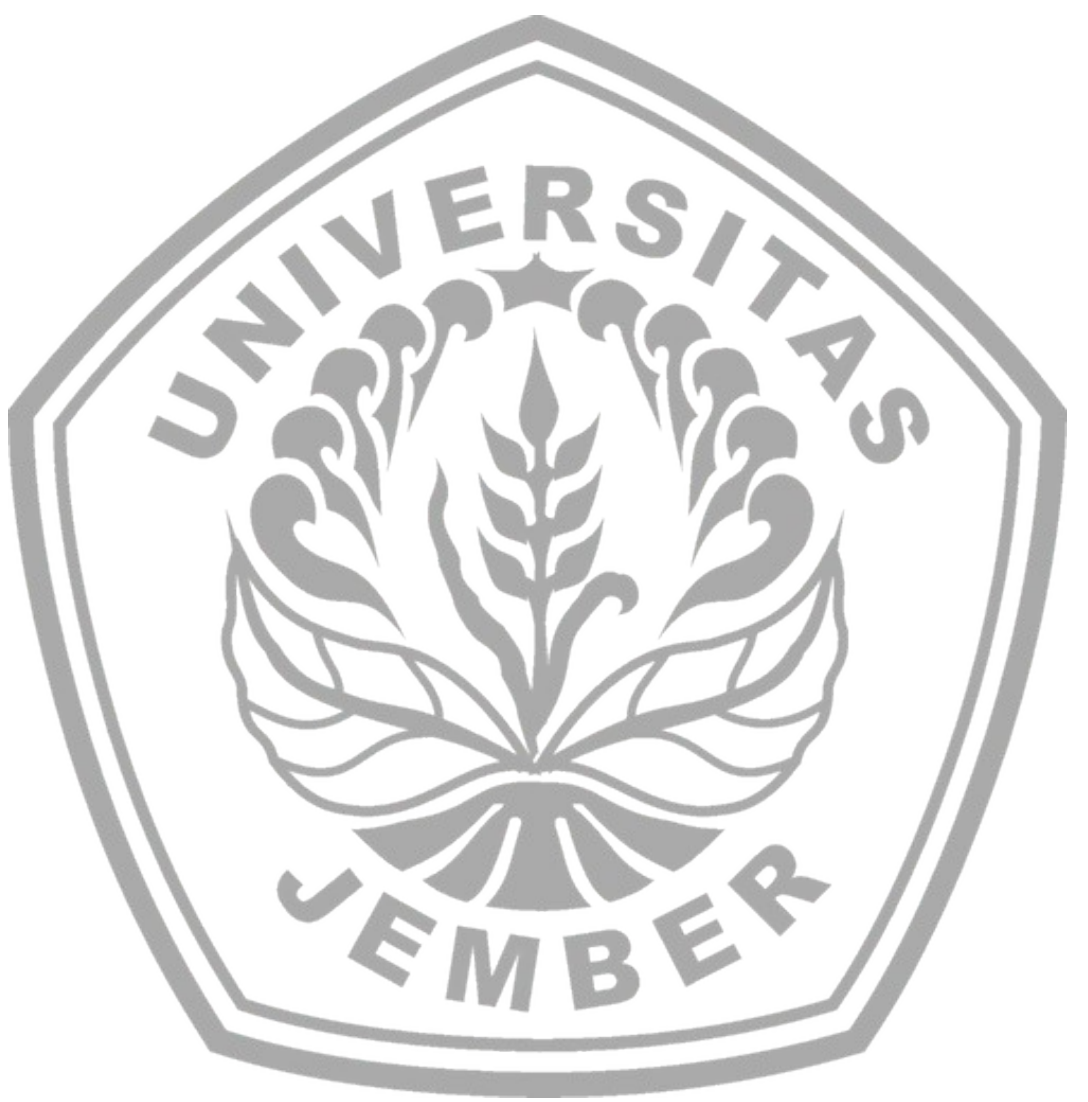

